\title{
The Impact of COVID 19 Biological Emergencies on Child Education in East Delhi, India
}

\author{
Anjali Diwakar
}

District Project Officer, Govt. of NCT, Delhi, India

\begin{abstract}
The increase in viral diseases intensity and frequency poses a threat to community infrastructure and affects the total well-being of children in regard to: access to food, health, school attendance, access to clean water and sanitation, physical and social security. Using both qualitative and quantitative data, this article provided an overview of biological disasters and their potential effects on children's access to quality education in East Delhi. The purpose of the study was to analyse school children's specific vulnerabilities to biological disasters that need to be taken into account in policy development. Research indicated that viral diseases cause loss of learning hours, loss of qualified personnel, outbreak of airborne diseases, high absenteeism and low syllabus coverage leading to children's poor academic performance. Children noted a range of experiences, from food insecurity to being withdrawn from school and sometimes forced into early marriages. These challenges compromise children's rights and access to quality education. This article therefore recommended that a culture of safety be promoted through disaster education, development of good medical facilities and enforcement of medical treatment guidelines. Findings also supported the need for adaptation strategies to ensure that the risks specific to school children are addressed.
\end{abstract}

Keywords : Biological Disaster, Education, Covid 19

\section{INTRODUCTION}

Globally, disaster risks are increasing in frequency and intensity; they are often unforeseen, serious, cause threats and may bring injury and death in worst cases (Stanley \& Williams 2000). This is of major humanitarian concern and poses a threat to the achievement of Millennium Development Goals (UN Centre for Regional Development [UNCRD] 2009), especially the second goal of achieving universal primary education. Disaster risks can either be time bomb moving in their onset or sudden and unexpected (Peek 2008). Epidemics and pandemics are amongst the most devastating natural disasters in the world and in India, in particular, where they have claimed lives and caused mental damage over the past decade. The most vulnerable, yet understudied, group when disaster risk initiates are school children. Biological emergencies effects to the socio-economic well-being of children have been well documented; yet, the impacts on children's access and right to quality education have received little attention (Masese et al. 2012). This has resulted in a lack of studies on the effects of biological emergencies on school children and their care takers in India.

Based on the hypothetical view that frequently occurring disaster emergencies threaten population, this study seeks to assess the effects of biological disasters on children's access and right to quality education in Delhi NCT. Using a case study approach, the article seeks to avail information on the 
challenges faced by school children in disaster-prone regions of East Delhi. The findings are a source of information in trying to address the challenges faced by children so that they can have access to quality education. Based on these research findings, it is expected that the education system in disaster-prone areas of Delhi-NCT will be enhanced in order for children to have equal access to quality education.

\section{Children and biological disaster risks}

Biological disaster risks threaten the lives, the rights and the needs of millions of children around the world and in India. Children are more vulnerable because of their unique physiological, psychological and developmental attributes. Children's age has affected their vulnerability and shapes their ability to cope and survive during a biological disaster situation. The effects of these disasters can affect their future development potential. If guardians' needs are met after a epidemic or pandemic disaster we cannot assume that children's needs are also met; children may require different forms of physical, social, mental and emotional support than adults (Peek 2008). The loss of livelihood due to migration and lockdown type situation can lead to extreme poverty and may lead to school dropouts and malnutrition. Dropping out of school may lead to early marriages and other social evils for the affected children, especially girl child's, and will result in them being trapped in a ferocious cycle of poverty. This may cause sluggish development in the community making it more vulnerable to man-made biological disasters. Children can be affected by biological disasters on their way to or from school, schools and homes may affect and a loss of livelihoods can lead to food insecurity, amongst others. Biological Disasters may sometimes result in missed school and delayed academic progress, missed social opportunities and increased exposure to diverse life stresses such as illness (Peek 2008). As summarized in Okuom et al.'s (2012) framework
(Figure 1), disasters augment the vulnerability of children. The framework elaborates factors that contribute to vulnerability, such as environmental, home, and infrastructural learner factors. The effects of biological disasters on school facilities must not be seen only in terms of the need to avert catastrophic damage that may destroy the livelihood but also in terms of preserving the lives of children during epidemic and related biological disasters. The concept of school safety is not limited to preventing the collapse of school buildings in disasters, and ensuring the safety of teachers and students, but rather extends to disaster risk reduction (UNCRD 2009).

The specific vulnerability of children has been highlighted by recent catastrophic event arise due to Covid 19 pandemic and resulting lock down. For example, the 2015 influenza A (H1N1) pdm09 outbreak in India that caused nearly 30,000 laboratories confirmed cases with more than 1700 deaths by March 15, 2015. Most of these cases were reported from the States of Rajasthan, Gujarat, Delhi, Jammu and Kashmir, Maharashtra, Madhya Pradesh, Telangana, Karnataka and Tamil Nadu (Manoj Murhekar et al.2016). Recurrent epidemics of encephalitis of unknown etiology have occurred in the country as a new biological emergency. Between 2008 and 2014, there have been more than 44,000 cases and nearly 6000 deaths from encephalitis in India, particularly in Uttar Pradesh and Bihar. In 2016, there has been a rise in encephalitis, with over 125 children reported to have died in one hospital in Gorakhpur alone (Jai Prakash Narayan et al, 2017). The potential impacts of these biological emergencies and disaster risks are multiplied in developing societies, where the largest population demographic is children.

Schools play a vital role in every population (Shaw \& Kobayashi 2001; Stanley \& Williams 2000) and they required to be well secured and protected. The 
concept of school safety was given a major focus by the UN International Strategy on Disaster Reduction (UNISDR) during the 2006-2007 World Disaster Reduction Campaign, with the theme 'Disaster reduction begins at school'. This theme was chosen by UNISDR because it is in line with the Priority 3 of the Hyogo Framework for Action 2005-2015, which states that 'Use knowledge, innovation and education to build a culture of safety and resilience at all levels' (UNISDR 2007:9) and because schools are the best locations for forging durable collective values and therefore suitable for building a culture of prevention and disaster resilience (ADPC 2007). The campaign identified the reasons, for which a school should be made safe, namely

1. Safety - as school premises can save lives,

2. Shelter - as schools be utilized as asylum in an emergency period,

3. Continuation of education - as education is disrupted in times of emergencies and

4. Resource preservation - as schools are valuable local investment of a country (ADPC 2007).

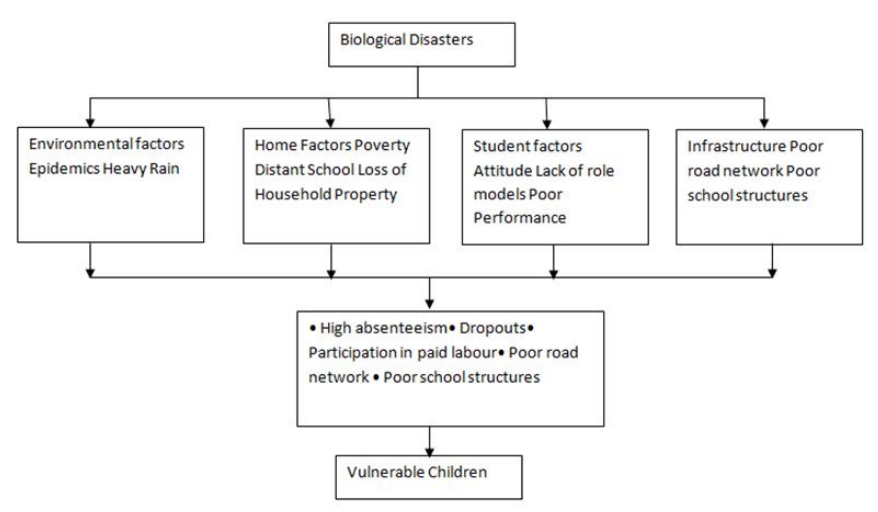

FIGURE 1: Factors that contribute to the vulnerability of children in biological disasters.

\section{Research method and design Study area}

East Delhi (a.k.a. Trans Yamuna) is an administrative district of the National Capital Territory of Delhi in India. It is bounded by the Yamuna River on the west,
North East Delhi to the north, Ghaziabad District of Uttar Pradesh state to the east, and Gautam Buddha Nagar District of Uttar Pradesh to the south. East Delhi has a population of 1,709,346 (2011 census) and an area of $64 \mathrm{~km}^{2}$, with a population density of 22,639 persons per $\mathrm{km}^{2}$. Administratively, the district is divided into three subdivisions: Gandhi Nagar, Preet Vihar, and Shahdara.

The study was carried out in Gandhi Nagar of the District, East Delhi; Gandhi Nagar is a middle-income commercial-cum-residential area in the East Delhi district of Delhi in the Trans-Yamuna area. It is most known for Gandhi Nagar Market, which is Asia's biggest readymade garments/textile market. Gandhi nagar has many shops and factories. Administratively it is one of the three subdivision of the East Delhi district (the others being Preet Vihar and Vivek Vihar) and one of the ten state legislative assembly constituencies under the East Delhi (Lok Sabha constituency), presently represented by Gautam Gambhir The area is one of the most congested colonies with a population of around 3.5 lakh. It has one of highest Muslim populations which are workers in the factory in the East Delhi constituency at 22\%. It is surrounded by other colonies including Geeta Colony, Seelampur and Krishna Nagar.

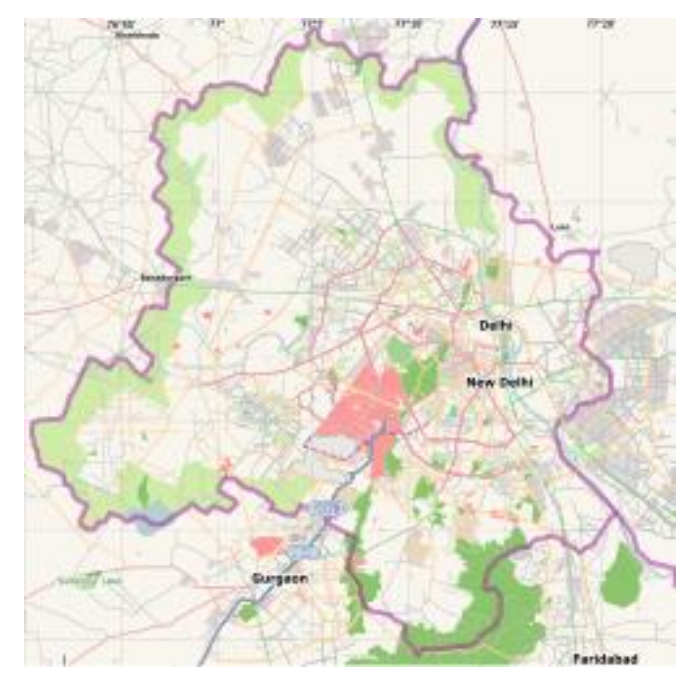

FIGURE 2: Map of Gandhi Nagar 
There are (Number) schools in the ward: (Number) primary and only

Secondary school. - All (Number) are government schools and the community provided land for their construction. Table 1 shows a list of the schools (letters were used for security reasons and the year the school was built. Most of the schools were built in areas that are not suitable for agriculture and some are in wetlands, such as the secondary school constructed in 2001, and others are very close to main rivers and streams.

The District of East, Delhi and Gandhi Nagar is located on the other side of River Yamuna or in the Trans-Yamuna area. It is bounded by the border of Uttar Pradesh comprising of Noida and Ghaziabad. It has a elevation of 239 Mtrs above sea level. The area suffers from disasters triggered by weather-related hazards, such as droughts and floods, and epidemics such as cholera and malaria. Although year-to-year droughts have been experienced, the present decade has seen various diseases that spread in very large magnitude. Jaundice and typhoid are caused by contaminated food and water. Residents of East Delhi have been complaining about the quality of water of the government pipelines for quite a while. The water that residents in East Delhi generally use is sometimes yellow and stinky.

Waterborne diseases are usually uncaused by drinking contaminated water which can cause diseases such as diarrhea, Cholera, Typhoid and Dysentery. According to the latest union health ministry data available, at least 10,738 deaths were caused due to water-borne diseases over five years to 2017. Unhygienic conditions and congested areas are also responsible for water borne diseases in East Delhi and especially Gandhi Nagar. The study area is most prone to biological disasters because it is at the confluence of Yamuna Rivers.
The population growth in the area increases the vulnerability of people, structures and goods and, worse still, people continue to construct in these densely populated areas. These climate extremes can also contribute to the outbreak of diseases such as cholera and malaria. Heavy rains tend to cause contamination of safe water contributing to the outbreak of cholera. Cross-border trading (DelhiUttar Pradesh) because of business brings affected people and contaminated food into the area. Stagnant water after the rain is conducive for mosquitoes to breed. Gandhi Nagar in East Delhi is also characterised by very high temperatures favoured by mosquitoes and malaria can create a crisis by imposing stress on the health system's ability to cope. People are losing their lives as a result of these manmade disasters

\section{Procedure}

Besides the collection and analysis of documentary data, the research questions were addressed using a variety of methods for triangulation. The data were collected between March 2020 and March 2021 using questionnaires, focus group discussions and observations through transect walks. A questionnaire was administered to 540 school children (260 boys and 280 girls). Questions asked included: 'Have you ever witnessed a biological disaster?', 'What could you say about the pandemics?, 'How did you manage to survive?' and 'What are the problems that you faced during the biological disaster?'.

Although school children in Delhi schools range from 5 to 18 years, the focus of this study was on children aged 9-18 years. The sample had the mean and modal age of 11 years in municipal primary schools and the mean age of 16 years, with modal age of 17 years, in secondary schools. Stratified comparative sampling was used to come up with the number of children to be interviewed per school. A proportionate sample 
was considered in each stratum (schools). The researcher selected a sample of about $10 \%$ of the 4715 school children to reach the 480 who participated in the study (Table 1). This is supported by Ott (1993) who noted that the sample size should be at least $10 \%$ of the study population.

Five focus group discussions were held: one at every other school. Each focus group consisted of 10 students ( 5 boys and 5 girls) between 9 and 18 years; 9-13 years for primary and 13-18 years for secondary school. In this study, children were seen as active subjects and not object of inquiry (Christensen \& James 2008). The researcher explained the inquiry to the children in their local language. The research procedures and aim were also explained clearly to the school children and teachers.

TABLE 1: School enrolment and sample size in the study area.

\begin{tabular}{lllll}
\hline School & Year Built & First Enrollment & $\begin{array}{l}\text { Estimated } \\
\text { enrollment in } \\
\mathbf{2 0 2 0}\end{array}$ & Sample size \\
\hline A & 2012 & 1041 & 700 & 70 \\
\hline B & 2013 & 965 & 670 & 70 \\
C & 2014 & 554 & 650 & 65 \\
D & 2015 & 420 & 500 & 40 \\
E & 2016 & 365 & 356 & 35 \\
F & 2017 & 320 & 278 & 28 \\
G & 2018 & 120 & 642 & 65 \\
H & 2019 & 144 & 329 & 32 \\
I & 2020 & 255 & 382 & 40 \\
J & 2021 & 214 & 340 & 35 \\
Total & & & 4847 & 480 \\
\hline
\end{tabular}

In all, 20 key informant interviews were conducted: with 5 school senior teachers, a councilor, a ward coordinator, 10 teachers, a district education officer, a ward councilor and village health workers. Field observations and transect walks were undertaken with the ward councilor and coordinator and school head teachers to assess the nature and level of damage caused by biological emergencies. The researcher also visited some of the places to assess the type of problems and the nature of the ways used by children going to school.

\section{Results}

\section{Vulnerability of schools and school children to biological emergencies}

All the schools in the area were vulnerable to COVID 19 but the level of vulnerability varied. Three schools are located on safe zones and were not considered physically vulnerable, but have pupils who cross containment zones coming to the same school. These schools were never affected by severe epidemics or pandemics but have been affected by viral diseases. Of the rest, two schools were marginally vulnerable, 
whilst the other five were vulnerable to biological disasters.

Although some schools were never directly affected by Covid 19, observations and consultations revealed that all schools (100\%) had poor post Covid 19 need assessment and were built by local people using local resources; no health emergency codes were used, subjecting school buildings to face health damage. Although the schools were built with bricks and cement, and maintained health hygiene conditions. Apart from physical weaknesses of classroom structures, it was observed that all the schools are located along unmaintained roads where cluster of people exists, which are impassable during the rainy. The roads connecting the communities have been contained, making them difficult to access by road. This reduces communication amongst the schools in the area. There was also lack of furniture in the schools, with children being forced to sit on the floor. This disrupts learning and can affect the concentration of children. It was observed that most of the floors where they sit were also dusty, exposing children to multiple risks such as respiratory diseases. Factors that contributed to the vulnerability of schools to biological disasters in the study area included terrain, poor structures, geographical location, climate change, lack of building standards, poverty and lack of resources (Table 2). School structures were built without new medical social distancing codes and were below standard, making them vulnerable to the compounding effects of epidemics and pandemics. All the schools (100\%) had dilapidated facilities which were never maintained.
Some had inadequate and temporary buildings. Two schools are located near slum area and were normally congested at outside, whilst four are located at the confluence of Yamuna River making them more vulnerable to backflows. Although the issue of climate change was mentioned as a contributing factor (35\%), 65\% disagreed that it led to vulnerability of schools. However, $100 \%$ agreed that because there was no enforcement of building codes as per new medical guidelines and standards in the area, most of the schools were below standard. Apart from medical emergency codes and standards being enforced, research also indicated that poverty and lack of resources to maintain school structures make them vulnerable to biological disasters.

Covid 19 pandemic have also been blamed for loss of learning hours affecting the quality of education. Indepth interviews indicated that most teachers are failing to cover the school syllabus both at primary and secondary schools. This was said to affect the performance of the children in this area, as they will sit for the national examinations with other pupils whose learning was never interrupted. This is in line with Amer (2007) and Okuom et al.'s (2012) research findings that disasters result in teachers failing to complete the syllabus, leading to poor performance. Apart from losing contact hours at school, children highlighted that sometimes they do not attend school because of containment zones and lockdown, as some of the roads and areas were completely sealed resulting in some communities being cut off: 
TABLE 2: Factors contributing to vulnerability of schools to biological disasters in East Delhi, as rated by teachers.

\begin{tabular}{|c|c|c|c|c|c|}
\hline Factors & \multicolumn{5}{|c|}{ Score } \\
\hline & SA & A & $\mathrm{DA}$ & SDA & Average \% \\
\hline Terrain & 4 & 9 & 7 & 0 & 69 \\
\hline Poor Structure & 3 & 12 & 5 & 0 & 75 \\
\hline $\begin{array}{l}\text { Geographical } \\
\text { location }\end{array}$ & 7 & 10 & 5 & 0 & 85 \\
\hline Climate Change & 2 & 5 & 10 & 3 & 35 \\
\hline $\begin{array}{l}\text { Lack of building } \\
\text { codes for standard } \\
\text { buildings }\end{array}$ & 7 & 13 & 0 & 0 & 100 \\
\hline $\begin{array}{l}\text { Poverty and lack } \\
\text { of resources }\end{array}$ & 12 & 8 & 0 & 0 & 10 \\
\hline
\end{tabular}

$\mathrm{n}=20$. SA, strongly agree; A, agree; DA, disagree; SDA, strongly disagree.

The highest rate of school absenteeism was recorded during the rainy season (June - August) (Figure 3); attendance during this period averaged $50 \%$, which implies that about half of the children do not attend school between June and August. Respondents highlighted that children in lower levels are normally compelled to stay at home a little longer because they cannot cross containment zones, which again affects their academic progress. Schools A, E and F were the most vulnerable to this form of absenteeism, with more than $50 \%$ of the children failing to attend school during the rainy season as viral infection increases in this season (Figure 3).

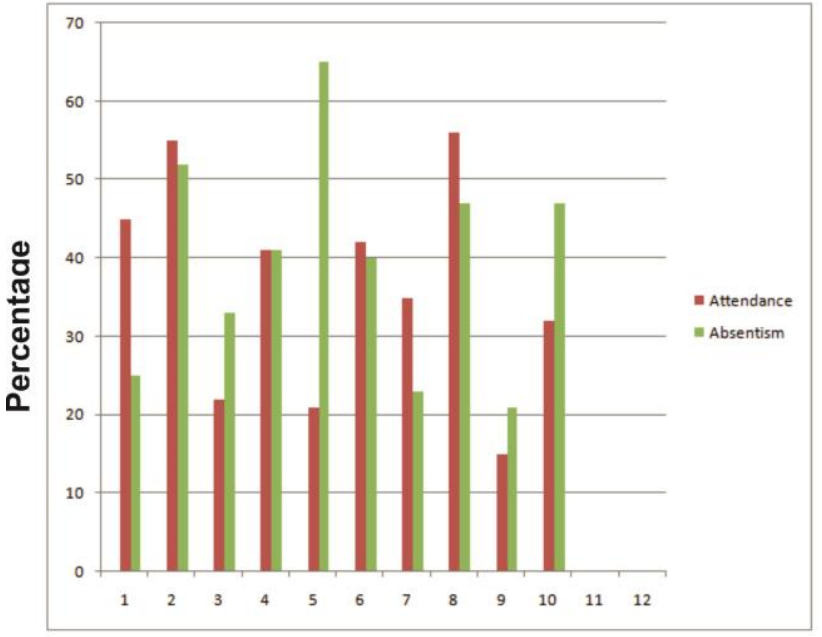

SCHOOL

FIGURE 3: Rate of school absenteeism during the rainy season (June - September).

Children have also dropped out of school as a result of biological disasters. Of the 5730 children in (Gandhi Nagar) aged 5-14 years, only about 4715 were being enrolled in school in 2020, implying that about 1015 children were not in school when they should have been. Reasons for low enrolment and dropouts are summarized in Table 3. 
TABLE 3: Factors that contribute to school dropouts and absenteeism, as rated by key informants and children.

\begin{tabular}{|c|c|c|c|c|c|c|}
\hline \multirow[t]{2}{*}{ Factors } & \multirow[t]{2}{*}{ Respondent } & \multicolumn{5}{|c|}{ Score } \\
\hline & & SA & A & DA & SDA & Average \% \\
\hline $\begin{array}{l}\text { Poor learning } \\
\text { environment }\end{array}$ & $\begin{array}{l}\text { Key informants } \\
\text { Children }\end{array}$ & $\begin{array}{l}10 \\
120\end{array}$ & $\begin{array}{l}7 \\
280\end{array}$ & $\begin{array}{l}3 \\
80\end{array}$ & $\begin{array}{l}0 \\
0\end{array}$ & $\begin{array}{l}85 \\
83\end{array}$ \\
\hline School too far & $\begin{array}{l}\text { Key informants } \\
\text { Children }\end{array}$ & $\begin{array}{l}7 \\
180\end{array}$ & $\begin{array}{l}7 \\
180\end{array}$ & $\begin{array}{l}8 \\
48\end{array}$ & $\begin{array}{l}0 \\
0\end{array}$ & $\begin{array}{l}60 \\
90\end{array}$ \\
\hline $\begin{array}{l}\text { Negative attitude } \\
\text { to learning }\end{array}$ & $\begin{array}{l}\text { Key informants } \\
\text { Children }\end{array}$ & $\begin{array}{l}20 \\
0\end{array}$ & $\begin{array}{l}20 \\
0\end{array}$ & $\begin{array}{l}0 \\
410\end{array}$ & $\begin{array}{l}0 \\
0\end{array}$ & $\begin{array}{l}100 \\
15\end{array}$ \\
\hline $\begin{array}{l}\text { Parents cannot } \\
\text { afford fees }\end{array}$ & $\begin{array}{l}\text { Key informants } \\
\text { Children }\end{array}$ & $\begin{array}{l}4 \\
60\end{array}$ & $\begin{array}{l}4 \\
60\end{array}$ & $\begin{array}{l}6 \\
30\end{array}$ & $\begin{array}{l}0 \\
0\end{array}$ & $\begin{array}{l}70 \\
94\end{array}$ \\
\hline Early marriages & $\begin{array}{l}\text { Key informants } \\
\text { Children }\end{array}$ & $\begin{array}{l}3 \\
100\end{array}$ & $\begin{array}{l}3 \\
100\end{array}$ & $\begin{array}{l}3 \\
130\end{array}$ & $\begin{array}{l}1 \\
40\end{array}$ & $\begin{array}{l}85 \\
65\end{array}$ \\
\hline $\begin{array}{l}\text { Poverty forcing } \\
\text { children to } \\
\text { participate in paid } \\
\text { labour }\end{array}$ & $\begin{array}{l}\text { Key informants } \\
\text { Children }\end{array}$ & $\begin{array}{l}9 \\
30\end{array}$ & $\begin{array}{l}9 \\
30\end{array}$ & $\begin{array}{l}4 \\
60\end{array}$ & $\begin{array}{l}2 \\
10\end{array}$ & $\begin{array}{l}70 \\
85\end{array}$ \\
\hline $\begin{array}{l}\text { Food insecurity- } \\
\text { cannot go to } \\
\text { school hungry }\end{array}$ & $\begin{array}{l}\text { Key informants } \\
\text { Children }\end{array}$ & $\begin{array}{l}0 \\
35\end{array}$ & $\begin{array}{l}0 \\
35\end{array}$ & $\begin{array}{l}12 \\
375\end{array}$ & $\begin{array}{l}0 \\
25\end{array}$ & $\begin{array}{l}40 \\
17\end{array}$ \\
\hline
\end{tabular}

Key informants, $n=20$; Children, $n=480$.

SA, strongly agree; A, agree; DA, disagree; SDA, strongly disagree.

Focus group discussions with children and key informants indicated that there were many biologicalrelated factors that contributed to school dropouts and absenteeism. Biological emergencies have contributed to poverty, food insecurity and damage to school infrastructure, creating a poor learning environment. As a result of poverty, some children are being forced into early marriages. Others end up having a negative attitude to learning because of poor learning environments. Lack of financial resources has forced some parents to withdraw their children from school. Both key informants and children agreed that a poor learning environment is the highest contributing factor to school dropouts and absenteeism. Children highlighted that some of the classes are conducted outside and therefore it is impossible for them to be conducted during the rainy and humid season. As a result, some children choose to be absent from school, whilst others end up dropping out.

Children always face challenges to access schools during the rainy and humid season because of road damages and travelling across roads. Roads in containment zones are barriers to children who cross to get to their respective schools and these were also mentioned as a contributing factor to a poor learning environment. It was indicated that children who cross roads in containment zones arrive at school infected, making them uncomfortable to learn with others so they end up dropping out or staying at home. 
There is also high teacher turnover. It was reported that that most of the teachers are relief members who never went through teacher education (Table 4). Qualified teachers were said to find it difficult to work in corona-prone areas and more so in areas that are not accessible by road. Of all the teachers in posts, only the head teachers in some schools had undergone teacher education in case of pandemics, whilst research also found that 3 of 10 head teachers also did not go through teacher education. This is also in line with Owiye (2005) and Okuom et al.'s (2012) findings that qualified teachers find it difficult to take up teaching posts in biological disaster-prone areas, leading to a shortage of health emergency qualified teachers and consequently affecting the quality of education. This has compromised the quality of education in the study area, leading to poor performance by students in corona affected areas. The absence of qualified teachers has meant that schools receive new relief teachers every term and so there is no continuity in learning assessment. Children end up getting a new teacher every 3 months, compromising the quality of results as there is no sense of belonging by the respective teachers. Apart from lack of continuity resulting from high teacher turnover, most of the time schools run without a full teacher establishment as some teachers refuse to teach in the Covid 19 pandemic-prone areas.

High rates of malnutrition were also reported in the area. Covid 19 have contributed to the loss of livelihoods in Gandhi Nagar area causing food shortages. Interviews revealed that the rate of absenteeism is high in families where there are food shortages and most of the children from these families do not perform well. This was also confirmed by Ayieko (2006), who revealed that because of food shortages after disasters, children normally help the family to get food, missing school in the process and eventually not performing well as a result of inconsistency in learning. Children highlighted that most of the time they miss school because they will be assisting parents to secure food for the family. This was said to contribute to high failure, dropout and absenteeism rates in the area.

Corona Pandemic exposes children to multiple health risks. Stagnant water in rainy season exposes children to other viral diseases such as cholera and malaria. Cholera was reported to be the most widespread illness causing loss of children's lives. The second most common disease is malaria, which was also reported to be claiming the lives of children in the study area. Interviews with health service officials indicated that they attend to epidemics like cholera and malaria sicknesses more during the rainy season. This agrees with reports by the UN Children's Fund (UNICEF) (2009) and Ochola (2009) that malaria and cholera are a health menace in flood zones and are aggravated by low socio-economic status. It was also revealed that more children die of these epidemics than any other disease, although figures supporting this could not be availed.

Biological disasters damage the mental ability and confidence of staff and children to cope up with such problems. It was reported that every time they experience such epidemics or pandemics, some classroom walls and toilets collapse becomes more vulnerable for public health emergencies. This poses a danger to children who spend most of the working hours in school. Children highlighted that because their classrooms benches may become infected they are always afraid and feel insecure. This is supported by Okuom et al.'s (2012) research findings that fear, insecurity and general high alert during water related emergencies reduced student's attention to learning, resulting to poor performance. The collapsed toilets forced some children to resort to bush toilets, leading to a high prevalence of cholera in schools as a result of water contamination. These unfavourable learning conditions have forced some children to drop out from school whilst others choose to stay away. 
Most children reside in traditional dwellings with congested buildings and lanes where houses are built closely and without any gaps. Such houses are prone to infection due to epidemics or pandemics. During the field visit, it was observed that $90 \%$ of the households had lost at least a hut. Ochola, Eitel and Olago (2010), in their research in African country, also noted that homes are as vulnerable as schools, which compounds the effects of water related problems on school children. Research revealed that some children whose houses were affected by pandemic dropped out of school, whilst others stayed at home trying to recover from the biological disaster impacts. This was said to increase the number of dropouts in the area and compromise the rights of children to education.

\section{Discussion}

\section{Response to biological disasters in Gandhi Nagar}

As a result of schools in Gandhi Nagar being vulnerable to biological disasters, the community has developed strategies to respond to their impacts in order to reduce vulnerability of children. Some of the coping mechanisms include: school absenteeism, early marriages, engaging in paid labour, infrastructure development, selling livestock and taking children out of school. Research findings highlighted that most parents cannot take risk for sending the children to schools due to pandemic and they end up taking their children away. Head teachers reported that most of the dropouts are noticed after a biological disaster. Some parents were reported to force their young daughters into marriage as a survival strategy, whilst some children are being forced into paid child labour to assist parents in getting food for the family. Research revealed that most children who drop out of school do so to work as house maids or herd boys. Selling of livestock is also one of the common coping mechanisms in the area. Most households own livestock and these act as a safety net in case of a biological disaster. However, it was revealed that most households do not sell livestock to pay school fees but to buy food stuffs. Although these coping mechanisms of pandemic seem to be viable for households, they are threatening children's lives. Children are becoming increasingly vulnerable in the congested areas of Gandhi Nagar.

TABLE 4: Teacher establishment status by 2020.

\begin{tabular}{llllll}
\hline School & $\begin{array}{l}\text { Teacher in } \\
\text { post }\end{array}$ & Qualified & $\begin{array}{l}\text { Non- } \\
\text { qualified(relief } \\
\text { teachers) }\end{array}$ & $\begin{array}{l}\text { School } \\
\text { enrollment }\end{array}$ & $\begin{array}{l}\text { Teacher- } \\
\text { student ratio }\end{array}$ \\
\hline A & 17 & 4 & 13 & 700 & 47 \\
B & 15 & 2 & 13 & 670 & 48 \\
C & 15 & 2 & 13 & 650 & 46 \\
D & 10 & 0 & 10 & 400 & 40 \\
E & 10 & 1 & 9 & 345 & 38 \\
F & 6 & 0 & 6 & 280 & 40 \\
G & 14 & 2 & 12 & 650 & 46 \\
H & 6 & 0 & 6 & 320 & 53 \\
I & 8 & 1 & 7 & 360 & 45 \\
J & 10 & 3 & 7 & 340 & 34 \\
Total & 111 & 15 & 96 & 4715 & 45 \\
\hline
\end{tabular}




\section{VII.Conclusion}

Some positive response strategies do exist, often in the form of food aid from the government and nongovernmental organisations such as Indian Red Cross, amongst others. Schools were also given free exercise and some textbooks from UNICEF India to ease the effects of disasters amongst children. To reduce the prevalence of disease like malaria in the area, the region is sanitized and fumigated on a yearly basis between through the guidelines of Ministry of Health and Child Care. With the help of community leaders and using local resources, a safe zone was also constructed to link the schools and the health centre with the community, to help children cross to schools in case of a biological disasters and emergencies. However, it appears that many of these response mechanisms are not well coordinated because of a lack of resources and poverty in the community.

Some of the community's response mechanisms, such as absenting and withdrawing children from school, sending children for paid labour and marrying children early, increase the vulnerability of children to pandemics and biological disasters. It was observed that upon visiting the study area 6 months after Covid 19 impact on community had blown off a roof top at one of the schools, it was discovered that nothing had been done to improve or renovate the buildings as per the health department advisory. A lack of resources was blamed for the delays in renovating the building as per health safety guidelines. Besides lack of resources in the rural communities of Delhi and East Delhi, disaster management is biased towards emergency response rather than mitigation. The tendency has been to wait and then start scurrying around for resources after a pandemics and biological disasters has hit communities. Lack of resources to respond to emergencies is exposing children to increased risk of biological disasters.
Biological Disasters result in disruptions in school children's learning, loss of contact hours, high rates of absenteeism and loss of qualified personnel affecting the quality of education in Gandhi Nagar area of East Delhi. Biological emergencies contribute to the loss of human lives, livelihoods and livelihood destruction, contributing to high levels of poverty. Biological Disasters also undermine the education for all campaigns in most developing countries, especially in India. However, although biological disasters are said to have major impacts on children's education and development, this research revealed that there is inadequate and, at times, inappropriate efforts to reduce the pandemic effects. Thus, the education system does not adequately cater for children in biological disaster-prone areas. They are treated the same as children in other areas and sit for the same state examinations, whilst the time lost as a result of biological disasters is not being compensated.

It has been observed that school children and infrastructure are vulnerable to biological disasters, compromising the children's rights to access to quality education, information, good sanitation, as well as their participation rights. There is need to integrate disaster risk reduction into the education curriculum for minimizing ill effects of biological disasters. School children need to be taught how to prepare, mitigate, prevent, respond to and recover from biological disasters. Both structural and nonstructural measures need to be put in place to reduce the vulnerability of schools and children to biological disasters. Health emergency codes and standards need to be enforced by policymakers to avoid the use of substandard school buildings and infrastructure, as these threaten the lives of children and teachers. Before any construction of public buildings, there is need for social distancing, sanitization, land-use planning and zoning so that areas that are fragile will 
not be occupied. There is also need for safe road maintenance to schools and provision of alternate routes so that all the communities and schools will be accessible by safe road movement.

\section{Acknowledgements}

\section{Competing interests}

The author declares that she has no financial or personal relationships that may have inappropriately influenced her in writing this article.

\section{REFERENCES}

[1]. Amer, A.H., 2007, Responses to traumatized children, Palgrave Macmillan, Hampshire.

[2]. Asian Disaster Preparedness Center (ADPC), 2007, Child-focused disaster risk reduction, Module 6: Community disaster risk reduction implementation, 16th Community-based disaster risk management course, Bangkok, 1627 July.

[3]. Ayieko, P., 2006, Guidebook for planning education in emergencies and reconstruction, International Institute for Education and Planning, Paris.

[4]. Christensen, P. \& James, A., 2008, 'Researching children and childhood: Cultures of communication', in P. Christensen \& A. James (eds.), Research with children: Perspectives and practices, 2nd edn., pp. 1-8, Routledge, London.

[5]. International Federation of Red Cross and Red Crescent Societies, 2007, Zimbabwe: Muzarabani floods, viewed 22 October 2011, from

http://www.ifrc.org/docs/appeals/07/MDRZM00 2a.pdf

[6]. Madamombe, E.K., 2004, Flood management practices - Selected flood-prone areas Zambezi Basin, Zimbabwe National Water Authority, Harare.

[7]. Masese, A., Opiyo R., Okayo, J. \& Ombui, N.M., 2012, 'Impact of floods on attainment of education for all (EFA) and vision 2030 in Nyando Basin', Kisumu County International Journal of Disaster Management and Risk Reduction 4(2), 19-31.

[8]. Musarurwa, C. \& Lunga, W., 2012, 'Climate change mitigation and adaptation: Threats and challenges to livelihoods in Zimbabwe', Asian Journal of Social Sciences \& Humanities 1(2), 25-32.

[9]. Ochola, S.O., 2009, Integrated flood hazard, vulnerability and risk assessment in Nyando River Catchment, Kenya: Options for landuse planning, Deutsche Nationalbibliothek, Heidelburge.

[10]. Ochola, S.O., Eitel, B. \& Olago, D.O., 2010, 'Vulnerability of schools to floods in Nyando River catchment, Kenya', Disasters 34(3), 732$754 . \quad$ http://dx.doi.org/10.1111/j.14677717.2010.01167.x

[11]. Okuom, H.A., Simatwa, E.M.W, Maureen, O.A. \& Wichenje, K.M., 2012, 'Assessment of factors that contribute to repetition and dropout of pupils in primary schools in flood prone areas of Nyando District, Kenya: An analytical study', Educational Research 3(2), 190-201.

[12]. Ott, R.L., 1993, An introduction to statistical methods and data analysis, 4th edn., Duxbury Press, Belmont.

[13]. Owiye, D.O., 2005, 'Trend in and factors affecting wastage in primary education in Siaya District', MEd thesis, Department of in Educational Management and Foundations, Maseno University.

[14]. Peek, L., 2008, 'Children and disasters: Understanding vulnerability, developing capacities, and promoting resilience - An introduction', Children, Youth and Environments 18(1), 1-29.

[15]. Shaw, R. \& Kobayashi, M., 2001, Role of schools in creating earthquake-safer environment 
disaster management and educational facilities, UNCRD, Nagoya.

[16]. Stanley, P. \& Williams, S., 2000, After disaster: Responding to the psychological consequences of disasters for children and young people, New Zealand Council for Educational Research, Wellington.

[17]. UN Centre for Regional Development (UNCRD), 2009, Reducing vulnerability of school children to earthquakes: A project of school earthquake safety initiative (SESI), viewed 22 October 2011, from http://www.preventionweb.net/files/2951_SESI

Outcomeallfinal.pdf

[18]. UN Children's Fund (UNICEF), 2009, Floods devastate Agadez Region of northern Niger with lingering effects, viewed 22 October 2011, from

http://www.unicef.org/infobycountry/niger_512 21.html

[19]. UN Office for Disaster Risk Reduction, 2007, Hyogo Framework for Action 2005-2015. Building the resilience of nations and communities to disasters, ISDR, Geneva, viewed 22 October 2011, from http://www.unisdr.org/we/inform/publications/ 1037

[20]. Wamukonya, N. \& Rukato, H., 2001, Climate change implications for southern Africa: A gendered perspective, viewed 14 May 2013, from

http://www.energia.org/fileadmin/files/media/p ubs/wamukonyarukato.pdf

\section{Cite this article as :}

Anjali Diwakar, "The Impact of COVID 19 Biological Emergencies on Child Education in East Delhi, India", International Journal of Scientific Research in Science and Technology (IJSRST), Online ISSN : 2395-602X, Print ISSN : 2395-6011, Volume 7 Issue 3, pp. 429-441, May-June 2020. Available at doi : https://doi.org/10.32628/IJSRST207390 Journal URL : http://ijsrst.com/IJSRST207390 